\title{
Enzyme immobilization: an overview on techniques and support materials
}

\author{
Sumitra Datta $\cdot$ L. Rene Christena $\cdot$ \\ Yamuna Rani Sriramulu Rajaram
}

Received: 2 February 2012/ Accepted: 20 May 2012 / Published online: 6 June 2012

(C) The Author(s) 2012. This article is published with open access at Springerlink.com

\begin{abstract}
The current demands of the world's biotechnological industries are enhancement in enzyme productivity and development of novel techniques for increasing their shelf life. These requirements are inevitable to facilitate large-scale and economic formulation. Enzyme immobilization provides an excellent base for increasing availability of enzyme to the substrate with greater turnover over a considerable period of time. Several natural and synthetic supports have been assessed for their efficiency for enzyme immobilization. Nowadays, immobilized enzymes are preferred over their free counterpart due to their prolonged availability that curtails redundant downstream and purification processes. Future investigations should endeavor at adopting logistic and sensible entrapment techniques along with innovatively modified supports to improve the state of enzyme immobilization and provide new perspectives to the industrial sector.
\end{abstract}

Keywords Enzyme immobilization - Techniques ·

Supports · Applications

\section{Introduction}

Enzymes or 'biocatalysts' are remarkable discovery in the field of bioprocess technology. Biocatalysis has been widely accepted in diverse sectors owing to their ease of production, substrate specificity and green chemistry. However, for large extent commercialization of these bio-

\footnotetext{
S. Datta $(\bowtie) \cdot$ L. R. Christena · Y. R. S. Rajaram

School of Chemical and Biotechnology, Shanmuga Arts,

Science, Technology and Research Academy (SASTRA)

University, Tirumalaisamudram, Thanjavur 613401,

Tamilnadu, India

e-mail: sumitra.datta@gmail.com
}

derived catalysts, their reusability factor becomes mandatory, failing which they would no longer be economic. Maintenance of their structural stability during any biochemical reaction is highly challenging. Consequently, immobilized enzymes with functional efficiency and enhanced reproducibility are used as alternatives in spite of their expensiveness. Immobilized biocatalysts can either be enzymes or whole cells (Kawaguti et al. 2006). Enzyme immobilization is confinement of enzyme to a phase (matrix/support) different from the one for substrates and products. Inert polymers and inorganic materials are usually used as carrier matrices. Apart from being affordable, an ideal matrix must encompass characteristics like inertness, physical strength, stability, regenerability, ability to increase enzyme specificity/activity and reduce product inhibition, nonspecific adsorption and microbial contamination (Singh 2009). Immobilization generates continuous economic operations, automation, high investment/capacity ratio and recovery of product with greater purity (D'Souza 1998). Several methods are used for immobilization and various factors influence the performance of immobilized enzymes (Table 1). Adsorption/carrier-binding method uses water-insoluble carriers such as polysaccharide derivatives, synthetic polymers and glass (Al-Adhami et al. 2002; Rosa et al. 2002; Wu and Lia 2008; Cordeiro et al. 2011). In cross-linking/covalent method, bi/multifunctional reagents such as glutaraldehyde, bisdiazobenzidine and hexamethylene diisocyanate are used (Lee et al. 2006; Singh 2009). Polymers like collagen, cellulose and $\kappa$-carrageenan are employed by entrapment method, while the membrane confinement method includes formulation of liposomes and microcapsules (Katwa et al. 1981; Wang and Hettwer 1982; Mislovicová et al. 2004; Hilal et al. 2006; Tümtürk et al. 2007; Rochefort et al. 2008; Jegannathan et al. 2010; Chen et al. 2011a, b; Klein et al. 2011). 
Table 1 Factors influencing performance of immobilized enzymes (Cao 2006)

\begin{tabular}{ll}
\hline Factors & Implications of immobilization \\
\hline $\begin{array}{l}\text { Hydrophobic partition } \\
\text { Microenvironment of carrier }\end{array}$ & $\begin{array}{l}\text { Enhancement of reaction rate of hydrophobic substrate } \\
\text { Hydrophobic nature stabilizes enzyme } \\
\text { Multipoint attachment of carrier }\end{array}$ \\
$\begin{array}{l}\text { Enhacer or arm of various types } \\
\text { of immobilized enzymes }\end{array}$ & Prevents enzyme deactivation \\
Diffusion constraints & Enzyme activity decreases and stability increases \\
Presence of substrates or inhibitors & Higher activity retention \\
Physical post-treatments & Improvement of enzyme performance \\
Different binding mode & Activity and stability can be affected \\
Physical structure of the carrier & Activity retention was often pore-size dependent \\
such as pore size & Carriers with large pore size mitigate diffusion limitation, \\
Physical nature of the carrier & leading to higher activity retention \\
\hline
\end{tabular}

This article reviews the existing techniques used for immobilization along with providing insights into the recent developments for each of them. We have tried to throw light on significant modifications with respect to the techniques and innovative support materials employed for immobilization of biocatalysts that have potential implication on future enzyme market.

\section{Different techniques used for immobilization}

\section{Adsorption}

Enzyme adsorption results from hydrophobic interactions and salt linkages where either the support is bathed in enzyme for physical adsorption or the enzyme is dried on electrode surfaces. Adsorbed enzymes are shielded from aggregation, proteolysis and interaction with hydrophobic interfaces (Spahn and Minteer 2008). Researchers have used eco-friendly supports like coconut fibers having good water-holding capacity and high cation exchange property; microcrystalline cellulose with irreversible binding capacity; kaolin with high enzyme retainability by chemical acetylation; and micro/mesoporous materials having thiol functionalized, large surface area ideally suited for reduction and oxidation reactions (Dey et al. 2002; Hernández et al. 2007; Karagulyan et al. 2008; Brígida et al. 2010; Mitchell and Ramírez 2011; Huang et al. 2011). Silanized molecular sieves have also been successfully used as supports for enzyme adsorption owing to the presence of silanols on pore walls that facilitate enzyme immobilization by hydrogen bonding (Diaz and Balkus 1996). Various chemical modifications of the currently used supports would definitely help in better immobilization. Water activity profiles of lipase adsorbed using polypropylenebased hydrophobic granules/Accurel EP-100 has been reported (Persson et al. 2000). It would be important to note that Accurel with smaller particle sizes increases reaction rates and enantiomeric ratios during biocatalyzation (Sabbani et al. 2006).

For better process control and economic production, Yarrowia lipolytica lipase was immobilized on octyl-agarose and octadecyl-sepabeads supports by physical adsorption that resulted in higher yields and greater (tenfold) stability than that of free lipase. This was accounted by the hydrophobicity of octadecyl-sepabeads that enhances affinity between the enzyme and support (Cunha et al. 2008). Candida rugosa lipase adsorbed on biodegradable poly (3-hydroxybutyrate-co-hydroxyvalerate) showed $94 \%$ residual activity after $4 \mathrm{~h}$ at $50{ }^{\circ} \mathrm{C}$ and reusability till 12 cycles (Cabrera-Padilla et al. 2011). These supports were preferred because they are less tough and crystalline than polyhydroxybutyrate. 1, 4-Butenediol diglycidyl ether-activated byssus threads have been suitable basement for urease that increased $\mathrm{pH}$ stability and retained $50 \%$ enzyme activity under dried conditions (Mishra et al. 2011). Eco-friendly supports of biological origin not only prevent cropping up of ethical issues, but also cut down the production costs. Of late, biocompatible mesoporous silica nanoparticles (MSNs) supports have been used for biocatalysis in energy applications owing to their long-term durability and efficiency (Popat et al. 2011).

\section{Covalent binding}

Covalent association of enzymes to supports occurs owing to their side chain amino acids like arginine, aspartic acid, histidine and degree of reactivity based on different functional groups like imidazole, indolyl, phenolic hydroxyl, etc. (D'Souza 1998; Singh 2009). Peptide-modified surfaces when used for enzyme linkage results in higher specific activity and stability with controlled protein orientation $(\mathrm{Fu}$ et al. 2011). Cyanogen bromide (CNBr)-agarose and $\mathrm{CNBr}$ activated-Sepharose containing carbohydrate moiety and 
glutaraldehyde as a spacer arm have imparted thermal stability to covalently bound enzymes (Hsieh et al. 2000; Cunha et al. 2008). Highly stable and hyperactive biocatalysts have been reported by covalent binding of enzymes to silica gel carriers modified by silanization with elimination of unreacted aldehyde groups and to SBA-15 supports containing cage-like pores lined by Si-F moieties (Lee et al. 2006; Szymańska et al. 2009). Increase in half-life and thermal stability of enzymes has been achieved by covalent coupling with different supports like mesoporous silica, chitosan, etc. (Hsieh et al. 2000; Ispas et al. 2009). Crosslinking of enzymes to electrospun nanofibers has shown greater residual activity due to increased surface area and porosity. Use of such nanodiametric supports have brought a turning point in the field of biocatalyst immobilization (Wu et al. 2005; Kim et al. 2006; Ren et al. 2006; Li et al. 2007; Huang et al. 2008; Sakai et al. 2010). Covalent binding of alcohol dehydrogenase on attapulgite nanofibers (hydrated magnesium silicate) has been opted owing to its thermal endurance and variable nano sizes (Zhao et al. 2010). Biocatalytic membranes have been useful in unraveling effective covalent interactions with silicon-coated enzymes (Hilal et al. 2006). Cross-linked enzyme aggregates produced by precipitation of enzyme from aqueous solution by addition of organic solvents or ionic polymers have been reported (Sheldon 2011). Different orientations of immobilized enzyme on magnetic nanoclusters obtained by covalent binding have found their applications in pharmaceutical industries owing to their enhanced longevity, operational stability and reusability (Yusdy et al. 2009). Maintaining the structural and functional property of enzymes during immobilization is one of the major roles played by a cross-linking agent. One such agent is glutaraldehyde, popularly used as bifunctional cross-linker, because they are soluble in aqueous solvents and can form stable inter- and intra-subunit covalent bonds.

\section{Affinity immobilization}

Affinity immobilization exploits specificity of enzyme to its support under different physiological conditions. It is achieved by two ways: either the matrix is precoupled to an affinity ligand for target enzyme or the enzyme is conjugated to an entity that develops affinity toward the matrix (Sardar et al. 2000). Affinity adsorbents have also been used for simultaneous purification of enzymes (Ho et al. 2004). Complex affinity supports like alkali stable chitosan-coated porous silica beads and agarose-linked multilayered concanavalin A harbor higher amounts of enzymes which lead to increased stability and efficiency (Shi et al. 2003; Sardar and Gupta 2005). Bioaffinity layering is an improvisation of this technique that exponentially increases enzyme-binding capacity and reusability due to the presence of non-covalent forces such as coulombic, hydrogen bonding, van der Waals forces, etc. (Sardar and Gupta 2005; Haider and Husain 2008).

\section{Entrapment}

Entrapment is caging of enzymes by covalent or noncovalent bonds within gels or fibers (Singh 2009). Efficient encapsulation has been achieved with alginate-gelatincalcium hybrid carriers that prevented enzyme leakage and provided increased mechanical stability (Shen et al. 2011). Entrapment by nanostructured supports like electrospun nanofibers and pristine materials have revolutionalized the world of enzyme immobilization with their wide-ranging applications in the field of fine chemistry, biomedicine biosensors and biofuels (Dai and Xia 2006; Kim et al. 2006; Wang et al. 2009; Wen et al. 2011). Prevention of friability and leaching and augmentation of entrapment efficiency and enzyme activity by Candida rugosa lipase entrapped in chitosan have been reported. This support has also been reported to be non-toxic, biocompatible and amenable to chemical modification and highly affinitive to protein due to its hydrophilic nature (Betigeri and Neau 2002). Entrapment by mesoporous silica is attributed to its high surface area, uniform pore distribution, tunable pore size and high adsorption capacity (Ispas et al. 2009). Simultaneous entrapment of lipase and magnetite nanoparticles with biomimetic silica enhanced its activity in varying silane additives (Chen et al. 2011a). Sol-gel matrices with supramolecular calixarene polymers have been used for entrapment of $C$. rugosa lipase keeping in view their selective binding and carrying capacities (Erdemir and Yilmaz 2011). Lipases entrapped $\kappa$-carrageenan has been reported to be highly thermostable and organic solvent tolerant (Tümtürk et al. 2007; Jegannathan et al. 2010).

\section{Materials used for fabrication of immobilization supports}

Natural polymers as supports

\section{Alginate}

Alginate derived from cell walls of brown algae are calcium, magnesium and sodium salts of alginic acid and have been extensively used for immobilization as xanthanalginate beads, alginate-polyacrylamide gels and calcium alginate beads with enhanced enzyme activity and reusability. Cross-linking of alginate with divalent ions (like $\mathrm{Ca}^{2+}$ ) and glutaraldehyde improves the stability of enzymes (Elçin 1995; Flores-Maltos et al. 2011). 


\section{Chitosan and chitin}

Natural polymers like chitin and chitosan have been used as supports for immobilization (Vaillant et al. 2000; Kapoor and Kuhad 2007). The protein or carbohydrate moieties of enzymes are used for binding them to chitosan (Hsieh et al. 2000). Chitosan has been used in combination with alginate where chitosan-coated enzymes had less leaching effect compared to alginate owing to the physical and ionic interactions between the enzyme and support (Betigeri and Neau 2002). Similarly, a wet composite of chitosan and clay proved to be more reliable for enzyme trapping, because it has hydroxyl and amino groups, which easily link with enzymes, together with good hydrophilicity and high porosity. Chitosan in the form of beads can entrap twice as much of the enzymes (Chang and Juang 2007). According to Chern and Chao (2005), the chitin-binding domain of chitinase A1 from Bacillus circulans has a high affinity to chitin; so, this property has been exploited to retain D-hydantoinase.

\section{Collagen}

Being a natural polymer, collagen has been used for immobilization of tannase employing glutaraldehyde as cross-linking agent (Katwa et al. 1981). $\mathrm{Fe}^{3+}$-collagen fibers proved to be excellent supporting matrix for catalase immobilization by retaining significant activity even after 26 reuses (Chen et al. 2011b).

\section{Carrageenan}

Carrageenan, a linear sulfated polysaccharide, has been consistently used for immobilizing a variety of enzymes, like lipase for improving stability (Tümtürk et al. 2007). This support is pseudoplastic in nature, which helps it to thin under shear stress and recover its viscosity once the stress is removed. Jegannathan et al. (2010) could achieve an encapsulation efficiency of $42.6 \%$ by the co-extrusion method using the same support for biodiesel production. Carrageenan has been reported as a cheap and durable support with better entrapment for lactic acid and $\alpha$ galactosidase enzyme (Rao et al. 2008; Girigowda and Mulimani 2006).

\section{Gelatin}

Gelatin is a hydrocolloid material, high in amino acids, and can adsorb up to ten times its weight in water. Its indefinite shelf life has attracted attention for enzyme immobilization. Gelatin has been utilized in mixed carrier system with polyacrylamide where cross-linking with chromium (III) acetate proved better than chromium (III) sulfate and potassium chromium (III) sulfate (Emregul et al. 2006). Calcium alginate with gelatin forms a good template for calcium phosphate deposition for enzyme immobilization, and gelatin in combination with polyester films promoted $75 \%$ loading efficiency, compared to previous studies which had $50 \%$ loading efficiency (Shen et al. 2011; Ateş and Doğan 2010).

\section{Cellulose}

This most abundant natural polymer has been widely used to immobilize fungi laccase, penicillin $\mathrm{G}$ acylase, glucoamylase, $\alpha$-amylase, tyrosinase, lipase and $\beta$-galactosidase (Al-Adhami et al. 2002; Mislovicová et al. 2004; Bryjak et al. 2007; Namdeo and Bajpai 2009; Labus et al. 2011; Huang et al. 2011; Klein et al. 2011). Diethylaminoethyl (DEAE)-modified cellulosic supports have longer storage capacity (Al-Adhami et al. 2002). Cellulose-coated magnetite nanoparticles have been used for starch degradation where the attachment of $\alpha$-amylase to cellulose dialdehydecoated magnetite nanoparticles resulted in the formation of a novel starch degrading system (Namdeo and Bajpai 2009). Immobilization with ionic liquid-cellulose film activated by glutaraldehyde gave better formability and flexibility (Klein et al. 2011).

\section{Starch}

Made of linear amylase and branched amylopectin units, starch has been used as enzyme immobilizer. Calcium alginate-starch hybrid supports were applied for surface immobilization and entrapment of bitter gourd peroxidase. Entrapped enzyme was more stable in the presence of denaturants like urea due to internal carbohydrate moieties, while surface-immobilized enzyme had superior activity (Matto and Husain 2009). Radiation grafting of substances like acrylamide and dimethylaminoethyl methacrylate onto starch are among the widely used industrial techniques for a high product yield (Dung et al. 1995; Raafat et al. 2011).

\section{Pectin}

This structural heteropolysaccharide along with $0.2-0.7 \%$ glycerol acts as plasticizer to reduce brittleness of support and has been used to immobilize papain and for development of new materials for skin injury treatment (Ceniceros et al. 2003). Pectin-chitin and pectin-calcium alginate support have enhanced thermal and denaturant resistance and catalytic properties of entrapped enzymes due to the formation of high stable polyelectrolyte complexes between the enzyme and the pectin-coated support (Gómez et al. 2006; Satar et al. 2008). 


\section{Sepharose}

CNBr-activated Sepharose-4B has been used to immobilize amylase and glucoamylase owing to its porosity and easy adsorption of macromolecules. Further matrix modifications like alkyl substituted Sepharose with multipoint attachment between hydrophobic clusters of the enzyme and alkyl residues of the support play a major role in retaining the catalytic properties at extremes of $\mathrm{pH}$, high salt concentrations and elevated temperatures (Hosseinkhani et al. 2003). Another example of modified Sepharose matrix is concanavalin A (Con A)-Sepharose 4B where biospecific interaction between the glycosyl chains of the enzyme and Con A plays a pivotal role in fabrication of various biosensors (Mirouliaei et al. 2007).

Synthetic polymers as supports

Ion exchange resins/polymers are insoluble supports with porous surface for enzyme trapping. Amberlite and DEAE cellulose, renewable matrices with large surface area, have been used for immobilization of $\alpha$-amylase (Kumari and Kayastha 2011). During white radish peroxidase immobilization, glutaraldehyde and polyethylene glycol act as an additive and protective layer around the active center of the enzyme to prevent the attack of free radicals (Ashraf and Husain 2010). Some synthetic polymers used as enzyme supports are stated as follows: polyvinyl chloride that prevents enzyme, cyclodextrin glucosyltransferase from thermal inactivation; polyurethane microparticles derived from polyvinyl alcohol and hexamethyl diisocyanate in the ratio of 1:3 with high enzyme loading and efficiency; UV-curable methacrylated/fumaric acid-modified epoxy that is proposed to be useful for industrial applications; polyaniline in two different forms, viz. emeraldine salt and emeraldine base powder used for covalent binding of $\alpha$ - amylase; glutaraldehyde-activated nylon for immobilizing lipase and UV-activated polyethylene glycol having high porosity employed for wastewater treatment (Abdel-Naby 1999; Kahraman et al. 2007; Pahujani et al. 2008; Romaskevic et al. 2010; Xiangli et al. 2010; Ashly et al. 2011).

Inorganic materials as supports

\section{Zeolites}

Zeolites or 'molecular sieves' are microporous crystalline solids with well-defined structures and shape-selective properties and are widely used in molecular adsorption. Microporous zeolites were found to be a better support for $\alpha$-chymotrypsin immobilization than microporous dealuminized ones because of the presence of more hydroxyl groups that form strong hydrogen bonds with the enzyme
(Xing et al. 2000). Likewise, $\mathrm{Na} \mathrm{Y}$ zeolite was used to immobilize lysozyme because it had higher activity compared to other supports as reported by Chang and Chu (2007). The heterogeneous surface of zeolites with multiple adsorption sites are considered to be suitable for modulating the enzyme and support interactions (Serralha et al. 1998).

\section{Ceramics}

Immobilization of Candida antarctica lipase on ceramic membrane showed that this inert support could be exploited for carrying out hydrolytic and synthetic reactions by limiting feedback inhibition (Magnan et al. 2004). Ceramic foams containing both macro $(77 \mathrm{~nm})$ and micropores $(45 \mu \mathrm{m})$ was found to be efficient in lowering diffusion rate and increasing the specific surface area (Huang and Cheng 2008). Another example of ceramics is toyonite whose variable pore structure can be modified using different organic coatings (Kamori et al. 2000).

\section{Celite}

Celite is highly porous diatomaceous, bioaffinity material and has been used for immobilization of lipase, polyphenol oxidases and $\beta$-galactosidase, because it is an inexpensive support having low polarity and large adhesion area (Khan et al. 2006; Liu et al. 2009; Ansari and Husain 2011). It provides resistance against high $\mathrm{pH}$ or temperature, urea, detergents and organic solvents (Khan et al. 2006). Celite acts as an additive in sol-gel matrix for $\omega$-transaminases immobilization. It has been preferred due to its chemical inertness and interconnected pore structure (Koszelewski et al. 2010).

\section{Silica}

Enzymes like lignin peroxidase and horseradish peroxidase (HRP) immobilized on activated silica have been effectively used for the removal of chlorolignins from eucalyptus kraft effluent (Dezott et al. 1995). $\alpha$-Amylase immobilized on silica nanoparticles improves cleaning performance of detergents. They have been used because of their nano-sized structures with high surface area, ordered arrangement and high stability to chemical and mechanical forces (Soleimani et al. 2011). Surface modifications of silica by amination of hydroxyl and reactive siloxane groups and addition of methyl or polyvinyl alcohol groups strengthen enzyme and support bonds (Rao et al. 2000; Shioji et al. 2003; Pogorilyi et al. 2007).

\section{Glass}

Glass is a highly viscous liquid and has been employed in immobilizing $\alpha$-amylase; phthaloyl chloride containing 
amino group functionalized glass beads was found to be robust and renewable for the process (Kahraman et al. 2007). Another enzyme nitrite reductase was immobilized on controlled pore glass beads, which served as a biosensing device for continuous monitoring (Rosa et al. 2002). Urease immobilized on glass $\mathrm{pH}$-electrodes has provided a stable biosensor for monitoring as low as $52 \mu \mathrm{g} / \mathrm{ml}$ urea in blood samples (Sahney et al. 2005).

\section{Activated carbon}

Both natural and hydrochloric acid-modified activated carbon has provided valuable support for enzyme adsorption (Alkan et al. 2009). Lately, mesoporous-activated carbon particles containing large contact sites for enzyme immobilization have been used for immobilizing acid protease and acidic lipases where catalytic efficiency has been significantly maintained after 21 cycles of reuse (Kumar et al. 2010; Ramani et al. 2011). It was also found that activated carbon with a high surface area (600-1,000 $\mathrm{m}^{2} \mathrm{~g}^{-1}$ ) and a significant fraction of its pore volume in the 300-1,000 A range was suitable for enzyme immobilization (Daoud et al. 2010).

\section{Charcoal}

Chemical modification of charcoal by adsorbing papain with sulfhydryl groups increased the number of active sites and has been utilized for recovery of mercury from aqueous solution and efficiently employed for industrial wastewater treatment (Dutta et al. 2009). Charcoal supports have been also used in food industries for immobilizing amyloglucosidase for starch hydrolysis without any crosslinking agent and has $90 \%$ catalytic activity (Rani et al. 2000). As reported earlier by Kibarer and Akovali (1996), charcoal is an excellent adsorbent with high adsorptive capacity and minimum fine particulate matter release.

\section{Applications and scope}

Biocatalysts are the key players in various industrial processes. Constant efforts are being made to improve the enzyme's activity, efficiency, reproducibility and stability during industrial processes (Wang et al. 2010). Production of regioselective and enantioselective compounds for biomedical application has been possible by immobilized enzymes (Ren et al. 2006; Lee et al. 2009). Glucose biosensors have been developed using electrospun PVA and surface-modified carbon nanotubes (Wen et al. 2011). Hydrogen peroxide biosensors have been devised using $\gamma$ aluminum trioxide nanoparticles/chitosan film-modified electrode (Liu et al. 2010). Agarose-guar has been

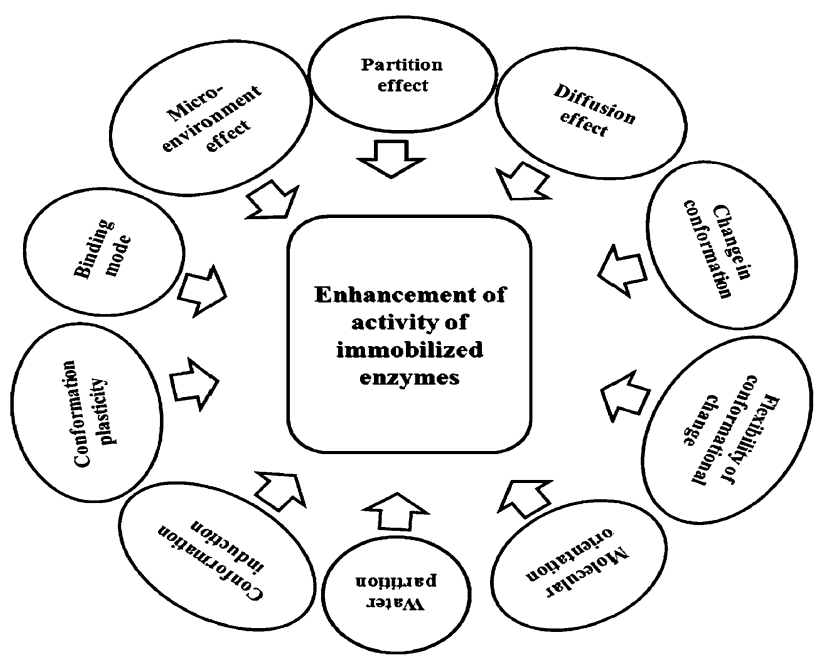

Fig. 1 Determinants of enzyme immobilization and activity

successfully utilized for designing phenol biosensors ( $\mathrm{Ba}$ gal and Karve 2006). Currently, keen efforts are being taken for increasing the stability of biosensors. Immobilization of biosensing enzymes into nanocavities showed significant results (Vamvakaki and Chaniotakis 2007). Biosynthesis of polyester has been facilitated by immobilized $C$. antarctica lipase $\mathrm{B}$, a greener alternative to petroleum-based conventional catalysts (Idris and Bukhari 2011). With the advent of nanotechnology, silica nanoparticles with immobilized laccase have been applied for elimination of micropollutants from wastewater (Zimmermann et al. 2011). Increasing environmental concerns have led to the use of immobilized biocatalysts for biodiesel production (Jegannathan et al. 2010).

The different factors influencing enzyme immobilization and the possible modifications for their enhancement in activity have been chalked out in Fig. 1.

\section{Conclusion}

With the vast array of research on enzyme immobilization, we can conclude that it is one of the most promising techniques for highly efficient and economically competent biotechnological processes in the field of environmental monitoring, biotransformation, diagnostics, pharmaceutical and food industries. Enzyme-based strategies are increasingly replacing conventional chemical methods in both laboratories and industries with attributes like efficiency, quicker performance and multifarious use. However, commercialization of immobilized enzymes is still at a lower pace because of their costs and storage problems. Research should be focused to overcome the current limitations related to immobilization techniques, so as to expand the horizon for all-round application. 
Acknowledgments The authors wish to express their sincere gratitude to Dr. S. Swaminathan (Director, Centre for Nanotechnology and Advanced Biomaterials and Dean, Sponsored Research, SASTRA, Thanjavur) for his constant support and encouragement.

Conflict of interest The authors declare that they have no conflict of interest.

Open Access This article is distributed under the terms of the Creative Commons Attribution License which permits any use, distribution, and reproduction in any medium, provided the original author(s) and the source are credited.

\section{References}

Abdel-Naby MA (1999) Immobilization of Paenibacillus macerans NRRL B-3186 cyclodextrin glucosyltransferase and properties of the immobilized enzyme. Process Biochem 34:399-405

Al-Adhami AJH, Bryjak J, Greb-Markiewicz B, Peczynska-Czoch W (2002) Immobilization of wood-rotting fungi laccases on modified cellulose and acrylic carriers. Process Biochem 37:13871394

Alkan S, Gür A, Ertan M, Savran A, Gür T, Genel Y (2009) Immobilization of catalase via adsorption into natural and modified active carbon obtained from walnut in various methods. Afr J Biotechnol 8:2631-2635

Ansari SA, Husain Q (2011) Lactose hydrolysis from milk/whey in batch and continuous processes by concanavalin A-celite 545 immobilized Aspergillus oryzae $\beta$-galactosidase. Food Bioprod Process. doi:10.1016/j.fbp.2011.07.003

Ashly PC, Joseph MJ, Mohanan PV (2011) Activity of diastase $\alpha$ amylase immobilized on polyanilines (PANIs). Food Chem 127:1808-1813

Ashraf H, Husain Q (2010) Use of DEAE cellulose adsorbed and crosslinked white radish (Raphanus sativus) peroxidase for the removal of $\alpha$-naphthol in batch and continuous process. Int Biodeter Biodegr 64:27-31

Ateş S, Doğan NS (2010) Properties of immobilized phenylalanine ammonia lyase and investigation of its use for the prediagnosis of phenylketonuria. Turk J Biochem 35:58-62

Bagal D, Karve MS (2006) Entrapment of plant invertase within novel composite of agarose-guar gum biopolymer membrane. Anal Chim Acta 555:316-321

Betigeri SS, Neau SH (2002) Immobilization of lipase using hydrophilic polymers in the form of hydrogel beads. Biomaterials 23:3627-3636

Brígida AIS, Calado VMA, Gonçalves LRB, Coelho MAZ (2010) Effect of chemical treatments on properties of green coconut fiber. Carbohydr Polym 79:832-838

Bryjak J, Aniulyte J, Liesiene J (2007) Evaluation of man-tailored cellulose-based carriers in glucoamylase immobilization. Carbohyd Res 342:1105-1109

Cabrera-Padilla RY, Lisboa MC, Fricks AT, Franceschi E, Lima AS, Silva DP, Soares CM (2011) Immobilization of Candida rugosa lipase on poly (3-hydroxybutyrate-co-hydroxyvalerate) a new eco-friendly support. J Ind Microbiol Biotechnol. doi: 10.1007/s10295-011-1027-3

Cao L (2006) Immobilized enzymes: past, present and prospects. In: Carrier-bound immobilized enzymes: principles, application and design. Wiley-VCH Verlag GmbH \& Co. KGaA, Weinheim. doi:10.1002/3527607668.ch1

Ceniceros EPS, Ilyina A, Esquivel JCC, Menchaca DR, Espinoza JCF, Rodriguez OEM (2003) Entrapment of enzymes in natural polymer extracted from residue of food industry: preparation methods, partial characterisation and possible application. Becth Mock 44:84-87

Chang YK, Chu L (2007) A simple method for cell disruption by immobilization of lysozyme on the extrudate-shaped $\mathrm{Na} \mathrm{Y}$ zeolite. Biochem Eng J 35:37-47

Chang MY, Juang RS (2007) Use of chitosan-clay composite as immobilization support for improved activity and stability of $\beta$ glucosidase. Biochem Eng J 35:93-98

Chen GC, Kuan IC, Hong JR, Tsai BH, Lee SL, Yu CY (2011a) Activity enhancement and stabilization of lipase from Pseudomonas cepacia in polyallylamine-mediated biomimetic silica. Biotechnol Lett 33:525-529

Chen S, Song N, Liao X, Shi B (2011b) Immobilization of catalase on ferric modified collagen fibers. Chin J Biotechnol 27:1076-1081

Chern JT, Chao YP (2005) Chitin-binding domain based immobilization of D-hydantoinase. J Biotechnol 117:267-275

Cordeiro AL, Lenk T, Werner C (2011) Immobilization of Bacillus licheniformis $\alpha$-amylase onto reactive polymer films. J Biotechnol 154:216-221

Cunha AG, Fernández-Lorente G, Bevilaqua JV, Destain J, Paiva LM, Freire DM, Fernández-Lafuente R, Guisán JM (2008) Immobilization of Yarrowia lipolytica lipase-a comparison of stability of physical adsorption and covalent attachment techniques. Appl Biochem Biotechnol 146:49-56

D’Souza SF (1998) Immobilized enzymes in bioprocess. Curr Sci 77:69-79

Dai D, Xia L (2006) Effect of lipase immobilization on resolution of (R, S)-2-octanol in non aqueous media using modified ultrastable-Y molecular sieve as support. Appl Biochem Biotechnol 134:39-49

Daoud FBO, Kaddour S, Sadoun T (2010) Adsorption of cellulase Aspergillus niger on a commercial activated carbon: kinetics and equilibrium studies. Colloid Surface B Biointerfaces 75:93-99

Dey G, Nagpal V, Banerjee R (2002) Immobilization of alphaamylase from Bacillus circulans GRS 313 on coconut fiber. Appl Biochem Biotechnol 102-103:303-313

Dezott M, Innocentini-Mei LH, Durán N (1995) Silica immobilized enzyme catalyzed removal of chlorolignins from eucalyptus kraft effluent. J Biotechnol 43:161-167

Diaz FJ Jr, Balkus KJ (1996) Enzyme immobilization in MCM-41 molecular sieve. J Mol Catal B-Enzym 2:115-126

Dung NA, Huyen ND, Hang ND, Canh TT (1995) Immobilization of urease on grafted starch by radiation method. Radiat Phys Chem 46:1037-1042

Dutta S, Bhattacharyya A, De P, Ray P, Basu S (2009) Removal of mercury from its aqueous solution using charcoal-immobilized papain (CIP). J Hazard Mater 172:888-896

Elçin YM (1995) Encapsulation of urease enzyme in xanthanalginate spheres. Biomaterials 16:1157-1161

Emregul E, Sungur S, Akbulut U (2006) Polyacrylamide-gelatin carrier system used for invertase immobilization. Process Biochem 38:27-30

Erdemir S, Yilmaz M (2011) Catalytic effect of calix[n]arene based sol-gel encapsulate or covalent immobilized lipases on enantioselective hydrolysis of (R/S)-naproxen methyl ester. J Incl Phenom Macrocycl Chem. doi:10.1007/s10847-011-9962-1

Flores-Maltos A, Rodríguez-Durán LV, Renovato J, Contreras JC, Rodríguez R, Aguilar CN (2011) Catalytical properties of free and immobilized Aspergillus niger tannase. Enzyme Res. doi: $10.4061 / 2011 / 768183$

Fu J, Reinhold J, Woodbury NW (2011) Peptide-modified surfaces for enzyme immobilization. PLoS ONE. doi:10.1371/journal.pone. 0018692

Girigowda K, Mulimani VH (2006) Hydrolysis of galacto-oligosaccharides in soymilk by $\kappa$-carrageenan-entrapped $\alpha$-galactosidase 
from Aspergillus oryzae. World J Microbiol Biotechnol 22:437-442

Gómez L, Ramírez HL, Neira-Carrillo A, Villalonga R (2006) Polyelectrolyte complex formation mediated immobilization of chitosan-invertase neoglycoconjugate on pectin-coated chitin. Bioproc Biosyst Eng 28:387-395

Haider T, Husain Q (2008) Concanavalin A layered calcium alginatestarch beads immobilized $\beta$-galactosidase as a therapeutic agent for lactose intolerant patients. Int J Pharm 359:1-6

Hernández MR, Kispert L, Ramírez ET, Rosales DR, Ulloa RZ, Ferrara JT (2007) Electron paramagnetic resonance analyses of biotransformation reactions with cytochrome P-450 immobilized on mesoporous molecular sieves. Biotechnol Lett 29:919-924

Hilal N, Kochkodan V, Nigmatullin R, Goncharuk V, Al-Khatib L (2006) Lipase-immobilized biocatalytic membranes for enzymatic esterification: comparison of various approaches to membrane preparation. J Membr Sci 268:198-207

Ho LF, Li SY, Lin SC, Hsu WH (2004) Integrated enzyme purification and immobilization processes with immobilized metal affinity adsorbents. Process Biochem 39:1573-1581

Hosseinkhani S, Szittner R, Nemat-Gorgani M, Meighen EA (2003) Adsorptive immobilization of bacterial luciferases on alkylsubstituted Sepharose 4B. Enzyme Microb Tech 32:186-193

Hsieh HJ, Liu PC, Liao WJ (2000) Immobilization of invertase via carbohydrate moiety on chitosan to enhance its thermal stability. Biotechnol Lett 22:1459-1464

Huang L, Cheng ZM (2008) Immobilization of lipase on chemically modified bimodal ceramic foams for olive oil hydrolysis. Chem Eng J 144:103-109

Huang XJ, Yu AG, Xu ZK (2008) Covalent immobilization of lipase from Candida rugosa onto poly (acrylonitrile-co-2-hydroxyethyl methacrylate) electrospun fibrous membranes for potential bioreactor application. Bioresource Technol 99:5459-5465

Huang XJ, Chen PC, Huang F, Ou Y, Chen MR, Xu ZK (2011) Immobilization of Candida rugosa lipase on electrospun cellulose nanofiber membrane. J Mol Catal B-Enzym 70:95-100

Idris A, Bukhari A (2011) Immobilized Candida antarctica lipase B: hydration, stripping off and application in ring opening polyester synthesis. Biotechnol Adv. doi:10.1016/j.biotechadv.2011.10. 002

Ispas C, Sokolov I, Andreescu S (2009) Enzyme-functionalized mesoporous silica for bioanalytical applications. Anal Bioanal Chem 393:543-554

Jegannathan KR, Jun-Yee L, Chan ES, Ravindra P (2010) Production of biodiesel from palm oil using liquid core lipase encapsulated in $\kappa$-carrageenan. Fuel 89:2272-2277

Kahraman MV, Bayramoglu G, Kayaman-Apohan N, Güngör A (2007) UV-curable methacrylated/fumaric acid modified epoxy as a potential support for enzyme immobilization. React Funct Polym 67:97-103

Kamori M, Hori T, Yamashita Y, Hirose Y, Naoshima Y (2000) Immobilization of lipase on a new inorganic ceramics support, toyonite, and the reactivity and enantioselectivity of the immobilized lipase. J Mol Catal B-Enzym 9:269-274

Kapoor M, Kuhad RC (2007) Immobilization of xylanase from Bacillus pumilus strain MK001 and its application in production of xylo-oligosaccharides. Appl Biochem Biotechnol 142:125138

Karagulyan HK, Gasparyan VK, Decker SR (2008) Immobilization of fungal beta-glucosidase on silica gel and kaolin carriers. Appl Biochem Biotechnol 146:39-47

Katwa LC, Ramakrishna M, Rao MRR (1981) Spectrophotometric assay of immobilized tannase. J Biosci 3:135-142

Kawaguti HY, Manrich E, Sato HH (2006) Production of isomaltulose using Erwinia sp. D12 cells: culture medium optimization and cell immobilization in alginate. Biochem Eng J 29:270-277
Khan AA, Akhtar S, Husain Q (2006) Direct immobilization of polyphenol oxidases on celite 545 from ammonium sulphate fractionated proteins of potato (Solanum tuberosum). J Mol Catal B-Enzym 40:58-63

Kibarer GD, Akovali G (1996) Optimization studies on the features of an activated charcoal-supported urease system. Biomaterials 17:1473-1479

Kim J, Jia H, Wang P (2006) Challenges in biocatalysis for enzymebased biofuel cells. Biotechnol Adv 24:296-308

Klein MP, Scheeren CW, Lorenzoni ASG, Dupont J, Frazzon, Hertz PF (2011) Ionic liquid-cellulose film for enzyme immobilization. Process Biochem 46:1375-1379

Koszelewski D, Müller N, Schrittwieser JH, Faber K, Kroutil W (2010) Immobilization of $\omega$-transaminases by encapsulation in a sol-gel/celite matrix. J Mol Catal B-Enzym 63:39-44

Kumar AG, Perinbam K, Kamatchi P, Nagesh N, Sekaran G (2010) In situ immobilization of acid protease on mesoporous activated carbon packed column for the production of protein hydrolysates. Bioresour Technol 101:1377-1379

Kumari A, Kayastha AM (2011) Immobilization of soybean (Glycine max) $\alpha$-amylase onto chitosan and amberlite MB-150 beads: optimization and characterization. J Mol Catal B-Enzym 69:8-14

Labus K, Turek A, Liesiene J, Bryjak J (2011) Efficient Agaricus bisporus tyrosinase immobilization on cellulose-based carriers. Biochem Eng J 56:232-240

Lee DH, Park CH, Yeo JM, Kim SW (2006) Lipase immobilization on silica gel using a cross-linking method. J Ind Eng Chem 12:777-782

Lee CH, Lin TS, Mou CY (2009) Mesoporous materials for encapsulating enzymes. NANO 4:165-179

Li SF, Chen JP, Wu WT (2007) Electrospun polyacrylonitrile nanofibrous membranes for lipase immobilization. J Mol Catal B-Enzym 47:117-124

Liu CH, Lin YH, Chen CY, Chang JS (2009) Characterization of Burkholderia lipase immobilized on celite carriers. J Taiwan Inst Chem E 40:359-363

Liu X, Luo L, Ding Y, Xu Y, Li F (2010) Hydrogen peroxide biosensor based on the immobilization of horseradish peroxidase on $\gamma-\mathrm{Al}_{2} \mathrm{O}_{3}$ nanoparticles/chitosan film-modified electrode. J Solid State Electrochem 15:447-453

Magnan E, Catarino I, Paolucci-Jeanjean D, Preziozi-Belloy L, Belleville MP (2004) Immobilization of lipase on a ceramic membrane: activity and stability. J Membr Sci 241:161-166

Matto M, Husain Q (2009) Calcium alginate-starch hybrid support for both surface immobilization and entrapment of bitter gourd (Momordica charantia) peroxidase. J Mol Catal B-Enzym 57:164-170

Mirouliaei M, Nayeri H, Shariat SZS, Atar AM (2007) Biospecific immobilization of lactoperoxidase on Con A-sepharose 4B. Sci Iran 14:303-307

Mishra N, Pithawala K, Bahadur A (2011) Byssus Thread: a novel support material for urease immobilization. Appl Biochem Biotechnol 165:1568-1576

Mislovicová D, Masarova J, Vikartovska A, Germeiner P, Michalkova E (2004) Biospecific immobilization of mannan-penicillin $G$ acylase neoglycoenzyme on Concanavalin A-bead cellulose. J Biotechnol 110:11-19

Mitchell S, Ramírez JP (2011) Mesoporous zeolites as enzyme carriers: synthesis, characterization, and application in biocatalysis. Catal Today 168:28-37

Namdeo M, Bajpai SK (2009) Immobilization of $\alpha$-amylase onto cellulose-coated magnetite (CCM) nanoparticles and preliminary starch degradation study. J Mol Catal B-Enzym 59:134-139

Pahujani S, Kanwar SS, Chauhan G, Gupta R (2008) Glutaraldehyde activation of polymer nylon-6 for lipase immobilization: enzyme characteristics and stability. Bioresour Technol 99:2566-2570 
Persson M, Wehtje E, Adlercreut P (2000) Immobilisation of lipases by adsorption and deposition: high protein loading gives lower water activity optimum. Biotechnol Lett 22:1571-1575

Pogorilyi RP, Siletskaya EY, Goncharik VP, Kozhara LI, Zub YL (2007) Immobilization of urease on the silica gel surface by solgel method. Russ J Appl Chem 80:330-334

Popat A, Hartono SB, Stahr F, Liu J, Qiao SZ, Lu GQ (2011) Mesoporous silica nanoparticles for bioadsorption, enzyme immobilisation and delivery carriers. Nanoscale 3:2801-2818

Raafat AI, Araby E, Lotfy S (2011) Enhancement of fibrinolytic enzyme production from Bacillus subtilis via immobilization process onto radiation synthesized starch/dimethylaminoethyl methacrylate hydrogel. Carbohyd Polym 87:1369-1374

Ramani K, Karthikeyan S, Boopathy R, Kennedy LJ, Mandal AB, Sekaran G (2011) Surface functionalized mesoporous activated carbon for the immobilization of acidic lipase and their application to hydrolysis of waste cooked oil: isotherm and kinetic studies. Process Biochem. doi:10.1016/j.procbio.2011.11.025

Rani AS, Das MLM, Satyanarayana S (2000) Preparation and characterization of amyloglucosidase adsorbed on activated charcoal. J Mol Catal B-Enzym 10:471-476

Rao MN, Kembhavi AA, Pant A (2000) Immobilization of endopolygalacturonase from Aspergillus ustus on silica gel. Biotechnol Lett 22:1557-1559

Rao CS, Prakasham RS, Rao AB, Yadav JS (2008) Functionalized alginate as immobilization matrix in enantioselective $\mathrm{L}(+)$ lactic acid production by Lactobacillus delbrucekii. Appl Biochem Biotechnol 149:219-228

Ren G, Xu X, Liu Q et al (2006) Electrospun poly(vinyl alcohol)/ glucose oxidase biocomposite membranes for biosensor applications. React Funct Polym 66:1559-1564

Rochefort D, Kouisni L, Gendron K (2008) Physical immobilization of laccase on an electrode by means of poly (ethyleneimine) microcapsules. J Electroanal Chem 617:53-63

Romaskevic T, Vikantiene E, Budriene S, Ramanaviciene A, Dienys G (2010) Immobilization of maltogenase onto polyurethane microparticles from poly (vinyl alcohol) and hexamethylene diisocyanate. J Mol Catal B-Enzym 64:172-176

Rosa CC, Cruz HJ, Vidal M, Oliva AG (2002) Optical biosensor based on nitrite reductase immobilised in controlled pore glass. Biosens Bioelectron 17:45-52

Sabbani S, Hedenström E, Nordin O (2006) The enantioselectivity of Candida rugosa is influenced by the particle size of the immobilizing support material Accurel. J Mol Catal B-Enzym 42:1-9

Sahney R, Puri BK, Anand S (2005) Enzyme coated glass pHelectrode: its fabrication and applications in the determination of urea in blood samples. Anal Chim Acta 542:157-161

Sakai S, Liu Y, Yamaguchi T, Watanabe R, Kawabe M, Kawakami K (2010) Immobilization of Pseudomonas cepacia lipase onto electrospun polyacrylonitrile fibers through physical adsorption and application to transesterification in nonaqueous solvent. Biotechnol Lett 32:1059-1062

Sardar M, Gupta MN (2005) Immobilization of tomato pectinase on Con A-Seralose 4B by bioaffinity layering. Enzyme Microb Tech 37:355-359

Sardar M, Roy I, Gupta MN (2000) Simultaneous purification and immobilization of Aspergillus niger xylanase on the reversibly soluble polymer Eudragit(TM) L-100. Enzyme Microb Tech 27:672-679

Satar R, Matto M, Husain Q (2008) Studies on calcium alginatepectin gel entrapped concanavalin A-bitter gourd (Momordica charantia) peroxidase complex. J Sci Ind Res India 67:609-615

Serralha FN, Lopes JM, Lemos F, Prazeres DMF, Aires-Barros MR, Cabral JMS, Ribeiro FR (1998) Zeolites as supports for an enzymatic alcoholysis reaction. J Mol Catal B-Enzym 4:303-311
Sheldon RA (2011) Characteristic features and biotechnological applications of cross-linked enzyme aggregates (CLEAs). Appl Microbiol Biotechnol 92:467-477

Shen Q, Yang R, Hua X, Ye F, Zhang W, Zhao W (2011) Gelatintemplated biomimetic calcification for $\beta$-galactosidase immobilization. Process Biochem 46:1565-1571

Shi Q-H, Tian Y, Dong X-Y, Bai S, Sun Y (2003) Chitosan-coated silica beads as immobilized metal affinity support for protein adsorption. Biochem Eng J 16:317-322

Shioji S, Hanada M, Hayashi Y, Tokami K, Yamamoto H (2003) Continuous surface modification of silica particles for enzyme immobilization. Adv Powder Technol 14:231-245

Singh BD (2009) Biotechnology expanding horizons. Kalyani, India

Soleimani M, Khani A, Najafzadeh K (2011) $\alpha$-Amylase immobilization on the silica nanoparticles for cleaning performance towards starch soils in laundry detergents. J Mol Catal B-Enzym $74: 1-5$

Spahn C, Minteer SD (2008) Enzyme immobilization in biotechnology. Recent Pat Eng 2:195-200

Szymańska K, Bryjak J, Jarzębski AB (2009) Immobilization of invertase on mesoporous silica to obtain hyper active biocatalysts. Top Catal 52:1030-1036

Tümtürk H, Karaca N, Demirel G, Şahin F (2007) Preparation and application of $\operatorname{poly}(N, N$-dimethylacrylamide-co-acrylamide) and $\operatorname{poly}(N$-isopropylacrylamide-co-acrylamide $) / \kappa$-Carrageenan hydrogels for immobilization of lipase. Int $\mathrm{J}$ Biol Macromol 40:281-285

Vaillant F, Millan A, Millan P, Dornier M, Decloux M, Reynees M (2000) Co-immobilized pectinlyase and endocellulase on chitin and nylon supports. Process Biochem 35:989-996

Vamvakaki V, Chaniotakis NA (2007) Immobilization of enzymes into nanocavities for the improvement of biosensor stability. Biosens Bioelectron 22:2650-2655

Wang HY, Hettwer DJ (1982) Cell immobilization in $\kappa$-carrageenan with tricalcium phosphate. Biotechnol Bioeng 14:1827-1838

Wang ZG, Wan LS, Liu ZM, Huang XJ, Xu ZK (2009) Enzyme immobilization on electrospun polymer nanofibers: an overview. J Mol Catal B-Enzym 56:189-195

Wang L, Wei L, Chen Y, Jiang R (2010) Specific and reversible immobilization of NADH oxidase on functionalized carbon nanotubes. J Biotechnol 150:57-63

Wen H, Nallathambi V, Chakraborty D, Barton SC (2011) Carbon fiber microelectrodes modified with carbon nanotubes as a new support for immobilization of glucose oxidase. Microchim Acta 175:283-289

Wu SC, Lia YK (2008) Application of bacterial cellulose pellets in enzyme immobilization. J Mol Catal B-Enzym 54:103-108

Wu L, Yuan X, Sheng J (2005) Immobilization of cellulase in nanofibrous PVA membranes by electrospinning. J Membr Sci 250:167-173

Xiangli Q, Zhe L, Yinglin Z, Zhengjia Z (2010) Immobilization of activated sludge in poly (ethylene glycol) by UV technology and its application in micro-polluted wastewater. Biochem Eng J 50:71-76

Xing GW, Li XW, Tian GL, Ye YH (2000) Enzymatic peptide synthesis in organic solvent with different zeolites as immobilization matrices. Tetrahedron 56:3517-3522

Yusdy, Patel SR, Yap MGS, Wang DIC (2009) Immobilization of L-lactate dehydrogenase on magnetic nanoclusters for chiral synthesis of pharmaceutical compounds. Biochem Eng J 48:13-21

Zhao Q, Hou Y, Gong GH, Yu MA, Jiang L, Liao F (2010) Characterization of alcohol dehydrogenase from permeabilized brewer's yeast cells immobilized on the derived attapulgite nanofibers. Appl Biochem Biotechnol 160:2287-2299

Zimmermann YS, Shahgaldian P, Corvini PFX, Hommes G (2011) Sorption-assisted surface conjugation: a way to stabilize laccase enzyme. Appl Microbiol Biotechnol 92:169-178 